\title{
Students Perceived Employability: A Systematic Literature Search and Bibliometric Analysis
}

\author{
Mohammad Idris NOORI* , Feza Tabassum AZMI**
}

Received: September 06, 2021. Revised: November 24, 2021. Accepted: November 29, 2021

\begin{abstract}
Among higher education students, perceived employability gained eminence in the last decades that attracted scholarly interests. Researchers theoretically and empirically studied the perceived employability though; inadequate preliminary review studies exist on this topic. Available researches mostly concentrated on a single approach. Thus, this study carried out a comprehensive review that comprised a systematic literature review (SLR) and bibliometric analysis that might boost understandings in the body of the literature. In the research process, the Scopus database from the 2008 to 2021 periods was used. The researchers set the search criteria that allowed the inclusion of 59 papers published in 45 peer-reviewed international journals. The paramount influential papers and prolific authors formulated the unit of this analysis. Furthermore, for the identification of thematic clusters and creating network maps, VOS viewer software was deployed. Citation analysis, co-authorship analysis, co-citation analysis, and co-occurrence of keywords analysis have generated interesting patterns which articulate the study results. The findings revealed enlightening insights on the content and characteristics of perceived employability, publication trends, highly cited papers, productive authors, contributing countries, repetitive themes, productive journals, and also unveiled gaps providing avenues for upcoming research works.
\end{abstract}

Keywords: Employability, perceived Employability, Systematic Literature Review, Bibliometric Analysis, and VOS viewer

JEL Classification Codes : J24, M1, M12

UDC: 331.1

DOI : https://doi.org/10.17015/ejbe.2021.028.03.

\footnotetext{
* Ph.D. research scholar, Aligarh Muslim University, Aligarh, India. E-mail: m.idris.noori@gmail.com

** MBA, PhD Professor, Aligarh Muslim University, Aligarh, India. E-mail: ftazmi@gmail.com

Copyright (C), 2021 Ala-Too International University.
} 


\section{Introduction}

Perceptions about employment were generated along with growth in the employability that witnessed a periodic evolution in a cycle of life, confronting a longshift transition to manifest the current facet as a multidimensional phenomenon. Moreover, in the twentieth century, employability was implied as a dichotomized notion; employable and unemployable individuals (Grazier, 1998). Thus, the concept in respect of economy thriven further hailing full employment that was aided by government policies which eased the access on employment (Rothwell et al., 2018). Furthermore, rapid changes in an agile environment due to a numerous range of factors like recruitment and dismissal policies, technological advancement, global market change, customer demand, and new regulations, gave impetus to organizational leadership to intensify work on a purposeful shift toward skillsbuilding orientation through improving total quality management, competitiveness, adaptability, and functional flexibility (Van Dam, 2004). Also, the expansion of dynamism in curriculum developments based on market-driven need assessments and experiential learning in the higher education area recorded outstanding stances in contributing to employability (Kanuka \& Smith, 2018). Although, the perception facet of the employability concept dated back to the 1950s and 1960s, its chronological evolution and individual employment greed (i.e., need for a job) fostered the perception facet of the employability that urge individuals, either workers or jobseekers, on skills development trends (Alrifai \& Raju, 2019). According to Rothwell and Jewell (2016), employability focused on personal belief pertinent to skill development, from the individual perspective. However, researchers' tendencies upheld concentration on three main approaches for an in-depth examination of the individual employability; the competency-based approach which investigated personal skills and abilities qualifying individuals in searching for job opportunities. The trait-based employability approach considered specific traits such as proactive attitudes amidst job searches. The perceived employability approach is gripped on intrinsic personal factors (i.e., self-capacities, attitudes, and skills) and external factors (i.e., labour market and students' qualifications) (Batistic \& Tymon, 2017). As per Vanhercke et al. (2015), two motives triggered authors to draw more attention to perceived employability; first, unlike other objective realities, the perceptions uphold a vibrant dynamism that encourages individuals to switch into a factional leap for drawing a career's roadmap. Secondly, the perceptions contain a holistic characteristic due to holding twofold factors (i.e., personal and contextual). Perceived employability is categorically sub-titled under the individual employability which is in general rooted in the employability concept affected by personal and contextual factors (Batistic \& Tymon, 2017). For wider contributions to the body of the literature, researchers have conducted empirical and theoretical research. Some researched works systematically reviewed the perceived employability for a better comprehension of its multiple aspects whereas few others conducted bibliometric analysis. Nevertheless, an integrated approach was lacking in the literature. Hence, the chief objective of this paper was to comprehensively review the content and as 
well as the prolific contributors of perceived employability through the use of a combined systematic literature search and bibliometric analysis. The present study used the Scopus database for data retrieval as it includes highly reputed journals that publish high prolific works, and the database was rarely considered by other researchers in the literature. However, the structure of this paper incorporated the introductory section followed by the literature review and then the research methodology articulated. After that, the analysis section was presented which was followed by research gaps, discussion, conclusion, and research future directions respectively.

\section{Literature Review}

Research gaps are often discovered through literature reviews. Analyses become likely feasible with the application of several methods applied by researchers for reviewing the literature. However, in the current literature, scholars conducted various kinds of studies, such as meta-review, systematic review, weight analysis, and scoping review to examine the desired topics pertinent to the perceived employability. Fajaryati and Akhyar (2020) conducted a systematic review on employability skills with the use of databases such as Science Direct, Springer, and IEEE; the search criteria preferred the inclusion of the paper published from 2014 to 2019 , that the adopted approach showed a combination of systematic and mapping review methods to retrieve the articles. The findings highlighted discrepancies between individual skills and employer demand. Subsequently, the review suggested a compatible career choice and renewal of personal employability skills according to employer demand (Fajaryati \& Akhyar, 2020). Also, Williams et al. (2015) assessed similarities and differences within the components of employability conceptualizations. Their systematic review included 16 eligible manuscripts that were published from 1960 to 2014. The study used Psyc Articles (PA), Psyc INFO (PO), Biz Source Elite (PSE), Educational Research Complete (ERC), Psychology and Behavioral Science Collection (PBSC), Web of Science (WS), Scopus, and Expanded Academic (EA) for retrieval of research papers. The findings illustrated four significant contributors such as governmental, organizational, higher educational, and individual to the evolution of employability concept. Artess et al. (2017) conducted a review analysis to assess employability approaches deployed by studies during 2012 and 2016. The review was based on 187 research papers and used Library Plus as a metasearch engine to retrieve the research papers. The findings highlighted an active and critical academic field that existed around employability which perceived a sustained growth along with ripening the field to become vital for the continuous development of employability in the higher education sector. Hazelzet et al. (2019) conducted a systematic search in the area of sustainable employability. The review is limited to full text that was published from 1997 to 2018 and aimed at assessing the quality of methodological studies. The study used six electronic databases, namely, Cinahl Ebsco, EconLit Ebsco, Embase, Psyclnfo Ebsco, Pubmed, and Web of Science, for data extraction. In the initial search, the 
researchers identified 596 articles and finalized with only seven papers. The findings indicated that the methodological quality of published researched papers ranged from moderate to weak. Moreover, Abelha et al. (2020) systematically reviewed graduate employability and competence development. The study examined 69 research papers published from 2009 to 2019. The study used databases namely Web of Science and Scopus for retrieval of the papers. The study results confirmed a lead in the number of European publications on the topics during the past decades. Also, it indicated a concern over higher education policies about graduate skills development. In addition, Alrifai and Raju, (2019) conducted research to review the trends of employability skills according to a specific industry like interior design. The research for retrieval included 105 papers. The findings suggested eight sets of desired communication skills, problem-solving, teamwork, design, project management, information technology, personal attributes, and pre-graduate work experiences. Fajaryati and Akhyar (2020) systematically reviewed the employability skills required to face future work demands. The review aimed at identifying the employers' needed employability skills and their application in the job context. The study used databases such as Springer, Science direct, and IEEE revealed that the employers demanded employability skills that represent team working, communication, problem-solving, and technological skills in the context of their study. The work of Guilbert et al. (2015) focused on a systematic review of employability and research prospects. It found that there were four major perspectives (i.e., educational, governmental, organizational, and individual) outlining the notion of employability. A different interpretation of employability according to those prospects was shown by the review results. In addition, researchers (Pitan \& Muller, 2019; Sumanasiri et al., 2015; Trullas et al., 2018; Huang \& Turner, 2018) studied the mediating role of experiential learning activities on the relations between university reputation and self-perceived employability of undergraduates, gender interactions, perceived organizational support, and university support respectively. Räty et al. (2019) studied the associations between students' perceived employability and students' self-ability. A significantly positive relation was revealed by the study. In addition, Dinc and Budic(2016) empirically examined the impact of personal attitude, subjective norm, and perceived behavioural control on entrepreneurial intentions of women. The findings revealed a significantly positive effect of the influential factors on women intention toward entrepreneurship. The study showed that personal attitude and perceived behavioural control empower women with high intention toward employment. Dahou and Hacini (2018) studied major determinants that effect employee success in Jordanian context. The study used regression analysis highlighted that sharing information, job design, decision making authority and transformational leadership effect employee empowerment in the workplace. However, according to the researcher's belief, in the existent literature, the authors mostly used a single method approach (i.e., either systematic review or few bibliometric analyses) in their respective review articles. Nonetheless, a comprehensive review would be suitable 
to enhance the intellectual structure; so, the field of study could be examined with the use of an integrated approach that represents a combination of systematic literature review (SLR) and bibliometric analysis techniques. Thus, using the comprehensive analysis, the present study had to address the research questions such as:

- What are the grass-roots and characteristics of perceived employability?

- What are the publication trends in the field of perceived employability?

- What are the most highly cited papers and productive authors in the field of the study?

- What are the most contributing countries and institutions in the field of the study?

- What are the utmost productive journals published relative topics?

- What are the top keywords that authors used to investigate their themes in the studied area?

- What are the literature gaps and future directions pertinent to perceived employability?

\section{Research Methodology}

The present study deployed a combination of systemic literature review (SLR) and bibliometric analysis techniques. SLR is a replicable, transparent (iterative) technique and found to reduce 'author's subjectivity through an objective baseline that excludes irrelevant papers. Due to the unavailability of systematic techniques, traditional reviews underwent by authors' subjectivity (Tranfield et al., 2003). Although technological upsurge and advanced electronic databases lend a hand to the researchers to conduct timely systematic reviews that perhaps reduced subjectivity risks. Also, in the initial phase, the researchers in this review executed the SLR via inputting the required keywords in the Scopus database search engine. At that point, the search was limited to retrieving the papers published from 2008 to 2021. Afterward, a systematic extraction was carried out on documents sample set through the exclusion and inclusion criteria. After retrieving entire manuscripts for eligibility set by the inclusion criteria, each manuscript was systematically scrutinized through the data extraction sheet. Later, within-study literature analysis was carried out for more support to the SLR process. Then, the bibliometric analysis is deployed to comprehend the research field's intellectual structure. However, other researchers have used a variety of software to conduct review analyses. But the present study used the VOS viewer software to display larger bibliometric maps in an interpretable manner that was lacked in previous software used in other bibliometric studies. Thus, the software provides more functionality in searching, scrolling, and zooming options that aid an in-depth map examination. However, the criteria excluded unpublished materials, conference articles, project reports, book chapters, monographs, and thesis. Also, the criteria requirements excluded the manuscripts not accessible in full text and so beyond the present study scope. With 
due care, the researchers in this review sorted the extracted data into CSV formats by the use of the Mendeley library to synthesize it for further analysis. Also, the Rpack program was deployed for pre-analysis of data preparation. Figure 1 represents the study design.

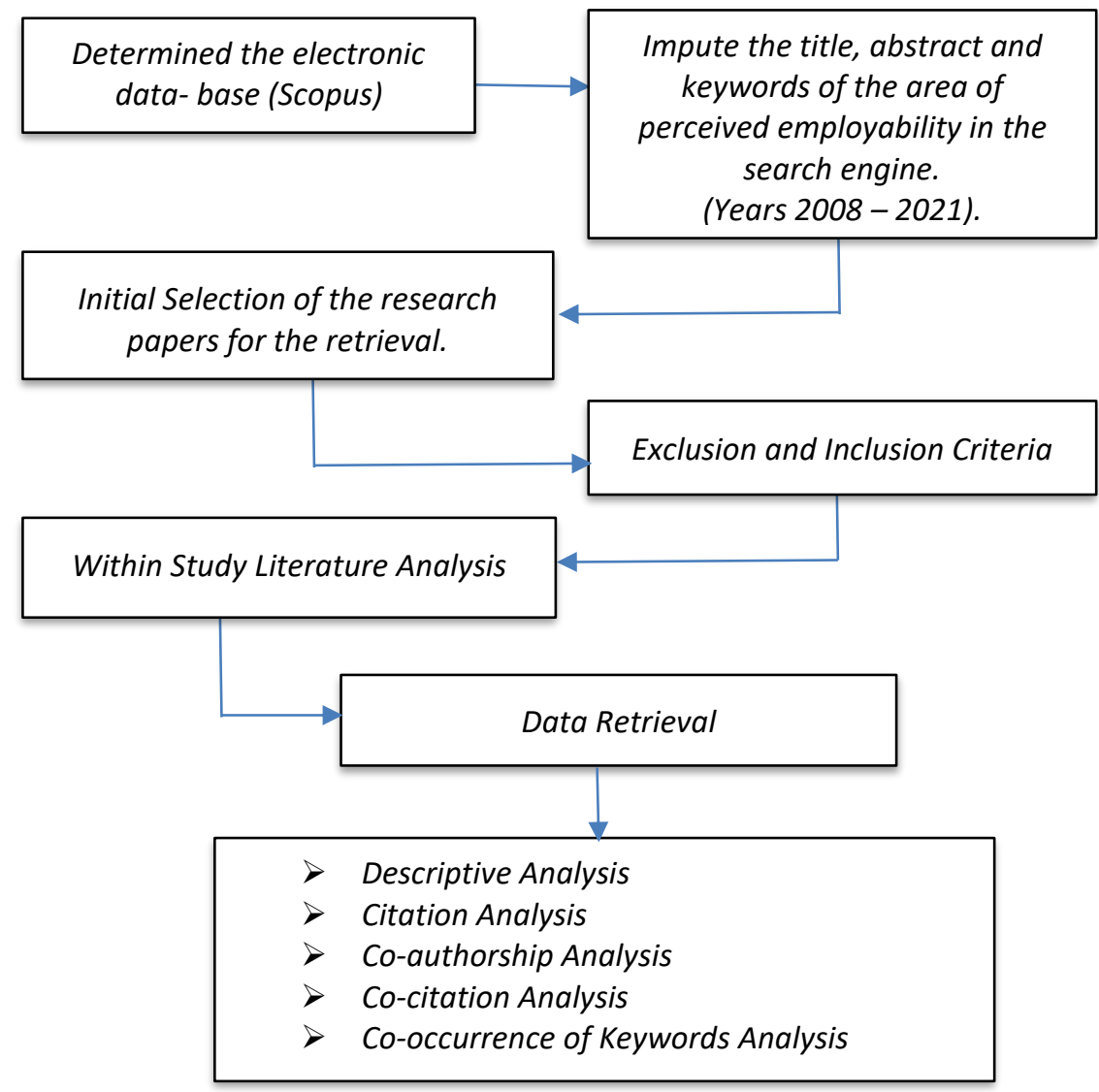

Figure 1. Study Design

\section{Analysis Results}

\subsection{Descriptive Information Pertinent to Data Collection}

By the present research process, it was found that 194 authors have written 59 articles in the area of perceived employability published in 45 reputed peer-reviewed journals. Among them, 190 articles were multi-authored with high collaboration and the rest four papers were single authored. However, the 'authors' collaboration index was estimated at 3.45. Likewise, the value of average citations per document 
counts at 53.3, in addition to 226 keywords in total. Descriptive analysis is depicted in Table 1.

\section{Table 1. Descriptive Information}

\begin{tabular}{lc}
\hline Description & Results \\
\hline Documents & 59 \\
\hline Sources & 45 \\
\hline Author keywords & 226 \\
\hline Period & $2008-2021$ \\
\hline Average citations per document & 53.3 \\
\hline Author & 194 \\
\hline Author per documents & 2.8 \\
\hline Co-Author per document & 3 \\
\hline Collaboration Index & 3.45 \\
\hline
\end{tabular}

\subsection{Publications Trend}

After the retrieval process, the researchers finalized with 59 articles published in 45 reputed peer-reviewed journals that were the most relevant to the research area and then exposed for the comprehensive review. The results showed that overall, the publication trends witnessed a gradual rise in its annual timeframe, indicating significant growth in the body of literature. However, research works were deemed as stagnant until 2016, but from 2017 onward, perceived employability emerged to have trapped the researcher's attention, and the outputs improved significantly. The annual publications growth rate began to gain momentum from the year 2017 and remain constant. In 2020 , the scientific production growth was calculated at $18 \%$, indicating a steady growth rate. Figure 2 represents the publications trend produced by the study results.

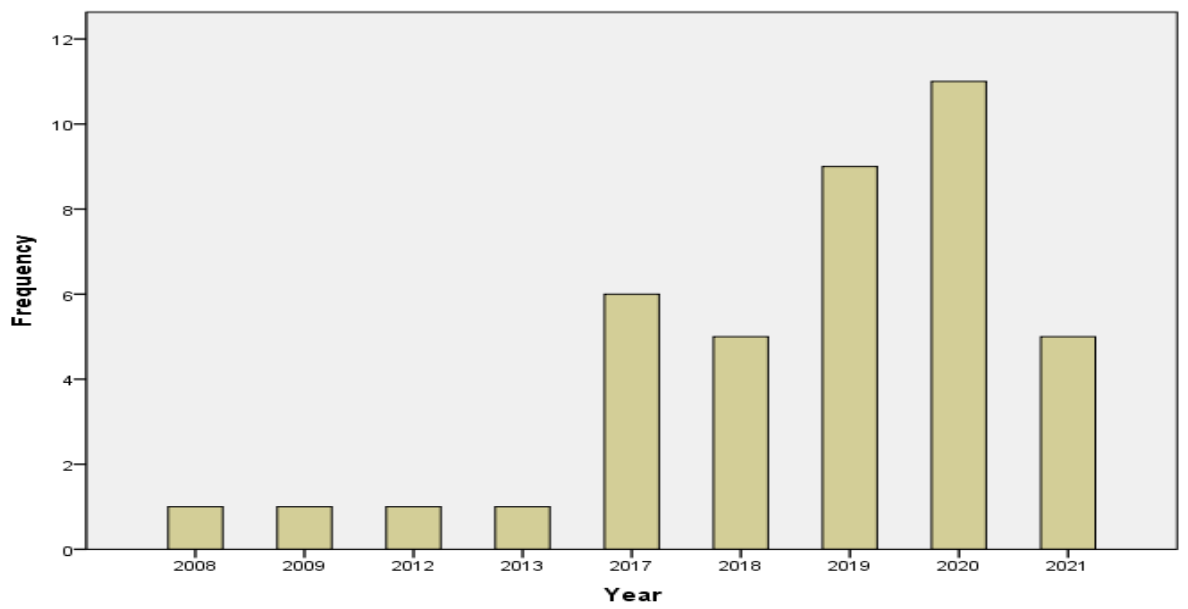




\section{Figure 2. Articles Published Per Year}

\subsection{Countries of Publications}

The geographical area was vital to show the top articles related to perceived employability which could help to identify the most contributing counties to the concept. Besides, contextual inspections may enhance the understanding of researchers about perceived employability at country levels which paves the way for better inferences and comparisons that leads to a projection of contextual gaps for future works. The present study highlights that the typical trends of research work in the area of perceived employability, conducted within the demesne of countries such as the United Kingdom, Australia, Spain, Malaysia, Italy, Netherlands, China, Indonesia, Belgium, Chile, Hong Kong, India, Nigeria, South Africa, Sweden, United States, and Bangladesh. Furthermore, the United Kingdom secured the highest digit of research publications $(n=18)$, followed by Australia $(n=11)$ and Spain $(n=6)$ among the mentioned countries that contributed to research products in the area of perceived employability. Figure3 depicts a geographical map of the research works.

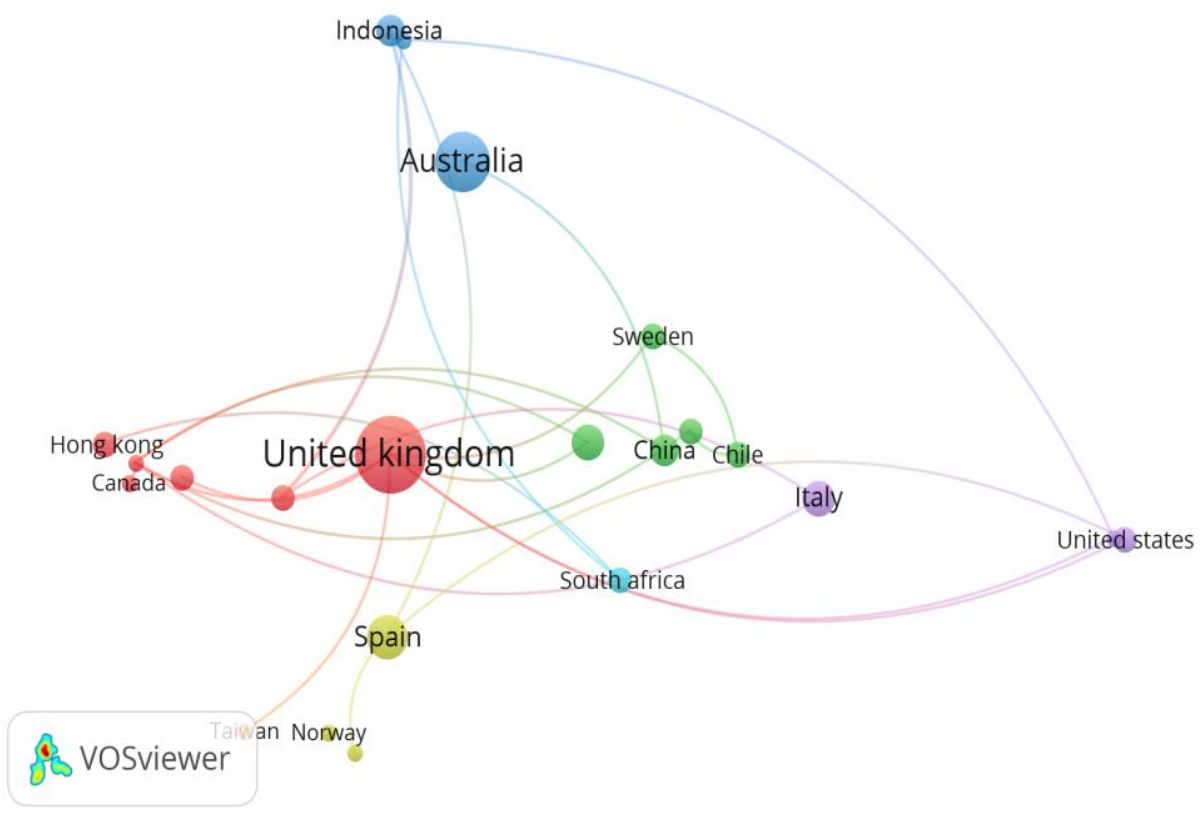

Figure 3. Geographical Map of Research Work

\subsection{Utmost Highly Cited Articles}

Highly cited articles are vital that help at identification of the utmost influential works provided new avenues in the field of perceived employability. The measurement 
indicator for the identification was based on the number of articles cited. On this account, the highest influential value perhaps would be the most highly cited article. Besides, researchers tended to refer to those scholarly articles that were highly cited and considered them as significant sources. However, to find out the utmost influential articles published in the field of perceived employability, the citation of 20 times was set as a cut-off limit. Then, the citation analysis results demonstrated that out of 59, only 10 documents met the fixed threshold limit. Table 2 exhibits the list of highly cited articles in the studied field.

\section{Table 2. Exhibits the List of Highly Cited Articles on Students' Perceived Employability}

\begin{tabular}{|c|c|c|c|c|}
\hline & $\begin{array}{ll}\text { Article Title } \\
\end{array}$ & Authors & Year & Citation \\
\hline 1 & $\begin{array}{l}\text { Self-Perceived Employability: Construction and } \\
\text { initial validation of a scale for university students }\end{array}$ & $\begin{array}{l}\text { Rothwell et } \\
\text { al. }\end{array}$ & 2008 & 158 \\
\hline 2 & $\begin{array}{l}\text { Self-Perceived Employability: investigating the } \\
\text { response of postgraduate students }\end{array}$ & $\begin{array}{l}\text { Rothwell et } \\
\text { al. }\end{array}$ & 2009 & 110 \\
\hline 3 & $\begin{array}{l}\text { The contributions of emotional intelligence and } \\
\text { social support for adoptive career progress among } \\
\text { Italian youth. }\end{array}$ & $\begin{array}{l}\text { Di Fabio and } \\
\text { Kenny. }\end{array}$ & 2014 & 81 \\
\hline 4 & $\begin{array}{l}\text { Networking Behaviour, Graduate Employability: A } \\
\text { social capital perspective }\end{array}$ & $\begin{array}{l}\text { Batistic and } \\
\text { Tymon }\end{array}$ & 2017 & 40 \\
\hline 5 & $\begin{array}{l}\text { Can University-industry linkages simulate student } \\
\text { employability? }\end{array}$ & $\begin{array}{l}\text { Ngoma and } \\
\text { Dithan Ntale }\end{array}$ & 2016 & 32 \\
\hline 6 & $\begin{array}{l}\text { Business Undergraduates perception of their } \\
\text { capabilities in employability skills: implications for } \\
\text { industry and higher education. }\end{array}$ & $\begin{array}{l}\text { Jackson \& } \\
\text { Wilton }\end{array}$ & 2012 & 31 \\
\hline 7 & $\begin{array}{l}\text { A tale of two university graduates perceived value } \\
\text { of entrepreneurship education }\end{array}$ & Jones et al. & 2017 & 27 \\
\hline 8 & $\begin{array}{l}\text { Mediating role of perceived employability in the } \\
\text { relationship between core self-evaluation and job } \\
\text { search behaviour. }\end{array}$ & Onyishii et al. & 2015 & 25 \\
\hline 9 & $\begin{array}{l}\text { Can university-industry linkages stimulate student } \\
\text { employability? }\end{array}$ & $\begin{array}{l}\text { Ishengom } \\
\text { and Vaaland }\end{array}$ & 2016 & 25 \\
\hline 10 & $\begin{array}{l}\text { Students' perceptions of education and } \\
\text { employability. }\end{array}$ & Donald et al. & 2018 & 24 \\
\hline
\end{tabular}

The utmost seminal work in 'students' perceived employability that was recorded by Rothwell et al. (2008) aimed at constructing scales for initial validation for university students under the title of self-perceived employability. The work had 158 citations which secured the first position and significantly contributed to the research field. In fact, the contribution laid a foundation for further scholarly empirical research in the field of perceived employability. Moreover, Rothwell et al. (2009), with 110 citations reserved the second position. Their work merely focused on the university students' responses on employability in addition to factors such as university image, the field of study, personal attitudes, and the labour market that were found as influential to 
the students' perceptions about their future employability. Also, the work of Di Fabio and Kenny (2014) occupied the third-highest position with 81 citations. It concentrated on how emotional intelligence and social support could contribute to career progress among Italian youth. Other scholars reopened new vistas of scholarly inquiries by investigating students' networking behaviour and its impacts on 'students' readiness to employment. Furthermore, Batistic and Tymon (2017) explored the graduate's networking behaviour based on social capital theory. The key objective was to identify how 'students' behaviour affects the social network that might assist them in obtaining a job. The work enlisted with 40 citations suggested that educational credentials alone might not feed the needs of the workplace if not accompanied with some desirable skills to empower a candidate to perform actual job responsibilities. In the given situation, universities preferred considering employer demands in their curriculums to build market-driven skills in their students to secure better employability. Nevertheless, Ngoma and Dithan Ntale (2016) found that the university and industry linkages provide students with better employability. The work confirmed 32 citations. Additionally, some other scholars approached the research realm by considering methodological perspective through applying the advanced level of statistical tools in the review process (Onyishi et al., 2015; Ishengom \& Vaaland, 2016; Donald, 2018).

\subsection{Top Cited Institutions}

Table 3 represents the top eleven utmost prolific institutions often cited based on twenty times citation limit. The institutions are in the countries such as the United Kingdom, the United States, Italy, Netherlands, Norway, Tanzania, and Australia. The citation parameter is used as an indicator of the most contributed institutions.

\section{Table 3. Utmost Highly Cited Institutions}

\begin{tabular}{clc}
\hline Rank & \multicolumn{1}{c}{ Organization } & Citation \\
\hline 1 & Centre for Studies in Higher education, Coventry University, UK & $158+$ \\
& & 110 \\
\hline 2 & School of Education, Nottingham Trent University, UK & 158 \\
\hline 3 & The Business School, Loughborough University, UK & 158 \\
\hline 4 & Lynch School of Education, Boston College, USA & 81 \\
\hline 5 & The University of Florence, Italy & 81 \\
\hline 6 & Department of Human Resource Studies, Tilburg University, Netherlands & 40 \\
\hline 7 & Portsmouth Business School, University of Portsmouth, Portsmouth, UK & 40 \\
\hline 8 & UIS School of Business, University of Stavanger, Norway & 32 \\
\hline 9 & University of Dares Salaam, Business School, Tanzania & 32 \\
\hline 10 & Faculty of Business and Law, Edith Cowan University, Australia & 31 \\
\hline
\end{tabular}

However, more specifically, the top seven leading institutions were Coventry University, Nottingham Trent University, and Southborough University with 158 citations, and Coventry University, Boston College, University of Florence, Tilburg University, University of Portsmouth, with 110, 81, 81, 40 and 40 citations respectively. The cooperative networks between some of these institutions shown 
in (Figure 6) included the business school, the center for studies in higher education, the department of human resource studies, the center for studies in higher education, and the UIS school of business though. Table 3 represents the utmost highly cited institutions.

\subsection{Analysis of Cited Journals}

Amongst the approaches that facilitate the examination of intellectual structure in particular research; is looking at the unit of analysis from a perspective of cited publications. Respectively, VOS viewer software provides a co-citation analysis option to study the cited publications in the field of interest. According to Misra and Khurana (2017), co-citation occurs when an author refers to two papers concurrently. Co-citation emerged as an effective instrument in measuring similarities between two documents from a contextual point of view (Surwase et al., 2011). Therefore, in the present study, the researchers conducted a co-citation analysis using the whole counting method to have a better mapping and better cocitation network. The threshold criterion was set to a minimum of 10 citations, which resulted in a total of 45 cited sources to meet the requirements out of 1,713 sources. The results were classified into three clusters that were visualized in three different colours. The co-citation pattern of 45 cited sources with a minimum of 10 times citation exhibited in Figure 4.

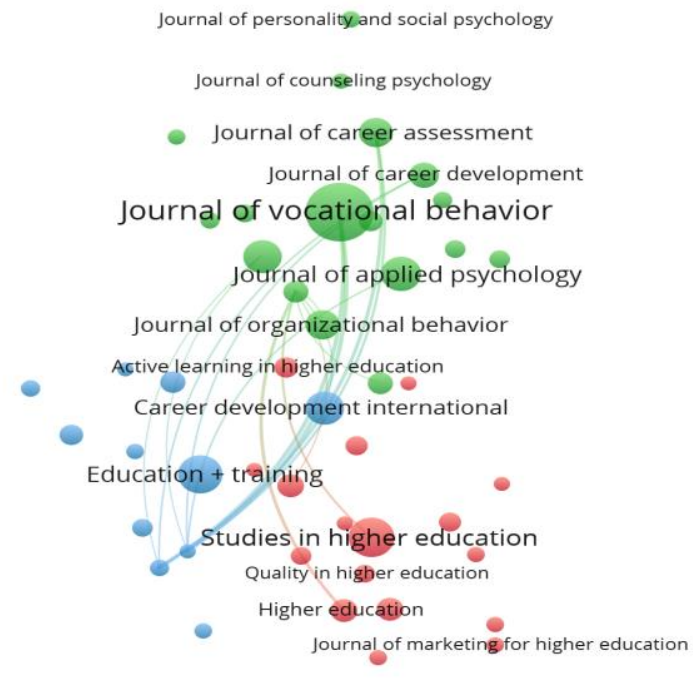

Figure 4. Cited Journals

However, cluster one visualized in red colour including seventeen journals such as studies in higher education, research and development, and active learning, which 
emerged as the most cited journals in this cluster. Cluster two is depicted in green colour that comprises seventeen journals which are considered the second-largest cluster. The leading eminent and impactful journals in this cluster are journals of vocational behaviour, applied psychology, personnel review, and journal of career assessment, journal of career development, journal of management, academy of management journal, and journal of organizational behaviour. Cluster three in blue colour entailed eleven items that included various journals such as education and training, career development international, and journal of business venturing. The mentioned journals emerged as the most cited in this cluster.

\subsection{Co-authorship Analysis}

VOS viewer provides a co-authorship option that eases the analysis of collaboration amongst authors, organizations, and countries which secure a synergistic effect. Through collaborative work, better quality research and innovative scientific research outputs can be obtained. Hence, for a desirable contribution toward the research production and quantity improvement of scientific research, many researchers seemingly adopted a collective approach. Therefore, in the present study, the researchers utilized the co-authorship analysis between authors and countries. While setting the threshold limit, the value for co-authorship fixed at least one document with twenty-five citations between 2008-2021. The analysis output confirmed that twenty-three authors met the threshold's limit. Documents are classified into eight clusters in different coloured visualizations. Amongst the clusters, the most vital co-authorship network comprised authors such as Rothwell A. et al. (2009) who have recorded with five co-authored documents followed by Onyishi et al. (2015) who have co-authored four documents. Figure 5 exhibits the coauthorship network map at the authors' level.

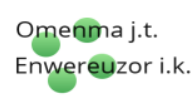

Batistic s.

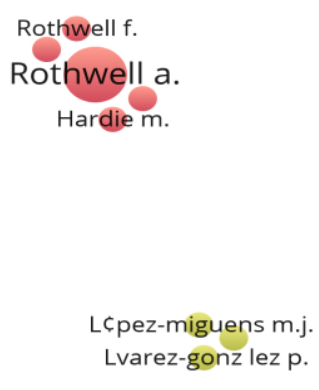

Rothwell f.

Rothwell a.

Hardie $\mathrm{m}$.

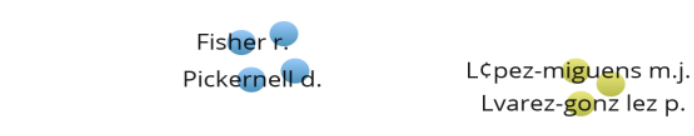

Di fábio a.

VOSviewer
Jackson d. Ishengoma e.

Figure 5. Co-Authorship Map 


\subsection{Analysis of Author Keywords}

According to researchers' suggestions, the co-occurrence analysis option in VOS viewer is chosen to examine author keyword occurrence for encapsulation of the thematic flow of knowledge that prevails among the researchers (Misra \& Khurana, 2017). Thus, in the present study, the researchers deployed the co-occurrence analysis of author keywords to comprehend the research trends that prevailed in the field of perceived employability. Above all, a sum of 226 author-keywords was extracted from the sorted list of 59 papers. To generate a better co-occurrence network of utmost recurrently used author-keywords, a value of at least two occurrences set in the thresholds; within the limit of 33 keywords, inception criteria met. The author's keywords co-occurrence network is shown in Figure 6. Furthermore, the network map exhibited that the often-studied themes are "employability" and "perceived employability". The term "employability" occurred twenty-one times while the "perceived employability" was shown fourteen times as per the analysis findings. Initially, the analysis output was grouped with thirty-three keywords into nine clusters that visualized in different colours with total link strength of seventy-seven.

\section{Figure 6. Author Keywords Map}

However, six items were classified in the first cluster such as employability, employment, factor analysis, graduate employment, self-perceived employability, and university commitment with total cluster link strength of twenty-seven. The second cluster comprised five items like: career development, careers, education, part-time work, and students. The third cluster included four items such as career 
planning, graduate employability, job search, and student perceptions. The fourth cluster contained four items that are curriculum designs, employability skills, and soft skills. The items such as career decision, self-efficacy, college students, emotional intelligence, and social support were grouped in the fifth cluster. Cluster sixth included three items that are graduate attributes, higher education, and satisfaction. Cluster seventh contained three items, such as perceived employability, social support, and work experience. Cluster eight comprised two items like extracurricular activities, university students, and finally, entrepreneurship education, and graduates were classified in cluster ninth.

\section{Research Gaps and Future Research Directions}

In the present research, the application of a combined method (i.e., systematic literature search and bibliometric analysis) helped to unveil the research progress in the body of literature and identification of gaps hampering. These critical outcomes help to propose some paths for forthcoming inspections in the area of perceived employability.

\subsection{Geographical Context of the Research Work}

In the present research, the geographical map represents the typical trends of research work in the area of perceived employability which conducted within the United Kingdom, Australia, Spain, Malaysia, Italy, Netherlands, China, Indonesia, Belgium, Chile, Hong Kong, India, Nigeria, South Africa, Sweden, United States, and Bangladesh. Other countries including Afghanistan's name was not shown in the network, which indicates an absence of empirical and theoretical papers on 'students', perceived employability in the context of those missing counties.

\subsection{Lack of Comparative Studies}

Most studies solely focused on content analysis aspects of perceived employability and its associated influential aspect. Research explored the source and origin where the concept of perceived employability originated (Grazier, 1998). Besides, some contextual and personal factors were investigated. However, comparative studies exploring different perspectives of several independent samples such as male and female, education levels, and employed and unemployed individuals have been absent except few (Chowdhury \& Miah, 2019; De Cuyper et al., 2011). Thus, future researchers can adopt a comparative approach to unveil perceptions of different independent samples toward employability.

\subsection{Lack of Qualitative Studies}

The literature in perceived employability lacks qualitative studies that can help generate novel scales to extend existing models. Researchers often concentrated on empirical papers to validate the adapted models in respective contexts. It observed 
that the lack of qualitative studies exists in the field of study. Future research can address this issue by giving due emphasis to the qualitative aspect.

\subsection{Paucity of Investigation on Moderating Effect}

The maximum proportion of research papers on self-perceived employability examined the correlations and factorial relations between independent and dependent variables. Often, a moderation role that affects relationships between predictor and predicted variables was lacking except few like (Pollack et al., 2012). Thus, a further investigation with more focuses on the moderation effect is suggested for having a better prediction.

\subsection{Lack of Studies on the Role of Socio-demographic Factors}

The most used themes by researchers for exploration of perceived employability were limited to a closed community that affects the concept. The most frequently used themes shown in the authors keywords map (figure 6) are employability skills, graduate employability, career plan, self-efficacy, higher education, job search, satisfaction, and employment. However, student social networks and social support (i.e., family and peers) as influential factors were lacking in the literature except few studies such as (Brannan et al., 2013; Abdullah et al., 2014). Hence, future researchers can consider the role of social ties and supports with their respective impact on perceived employability in their potential works.

\section{Discussion}

The present study provided relevant answers to the seven research questions modeled in the literature section. However, corresponding to question one, the findings revealed that perceived employability refers to individuals' perceptions about their employability skills that perhaps enable them to gain employment. Also, the term is used as an approach that involves further intrinsic personal factors (i.e., self-capacities, attitudes, and skills) and external factors (i.e., labour market and students' qualifications which unveils its holistic notion over other themes associated with employability. Question two addresses the publication trends in the research literature. So, the findings illustrated significant growth in the body of literature pertinent to perceived employability. As per the study outputs, the research works were stagnant until the year 2016 but from 2017 onwards, perceived employability emerged to have trapped the attention of researchers, and research work outputs improved significantly. The annual publications growth rate began to pick up momentum from the year 2017 and remained constant yet. The exploration of the most highly cited papers and productive authors is articulated in question three. Pertinent to the most prolific and influential authors in perceived employability, the study found that (Rothwell et al., 2008; Di Fabio \& Kenny, 2014; Batistic \& Tymon, 2017; Ishengoma \& Vaaland, 2016) from the United Kingdom, Italy, and the United States, respectively emerged as the most influential researchers in this field with a maximum number of scientific contributions and citation scores. So, the top-cited 
works "Self-Perceived Employability construction and initial validation of a scale for university students of Rothwell et al. (2008), "Self-Perceived Employability: investigating the response of postgraduate students" of Rothwell et al. (2009), and "The contributions of emotional intelligence and social support for adoptive career progress among Italian youth" of Di Fabio and Kenny (2014) ranked as first, second and third respectively. Corresponding to question four regarding the most contributed countries and institutions, it was found that the United Kingdom recorded the highest number of research publications followed by Australia and Spain whereas Coventry University, Nottingham Trent University, Loughborough University, Coventry University, Boston College, University of Florence, Tilburg University, and University of Portsmouth were found the most contributed institutions to the field of study. As far as prolific journals are concerned, as mentioned in question five, the study findings revealed that 45 journals met the threshold criteria, the journals such as studies in higher education, higher education research and development, higher education, and active learning in higher education, journal of vocational behaviour, journal of applied psychology, personnel review, journal of career assessment, journal of career development, journal of management, academy of management journal, and journal of organizational behaviour, education and training, career development international, and journal of business venturing emerged as most prolific journals in the field of study. Relative to question six, the network map of author keywords exhibits that the utmost largely studied concept is "employability" followed by "perceived employability". The term employability occurred 21 times and was followed by "perceived employability with 14 occurrences. This indicates the significance of the themes flowing amongst the researchers in the studied field. Other themes also within the 33 keywords met the threshold limit, which had lesser occurrences comparatively.

\section{Conclusions and Future Directions}

Amidst reviewing the existing literature, within the knowledge and the capacity the searchers can assert that the present study is considered as of a pioneering work carried out in the field of 'student's perceived employability, deploying SLR and bibliometric analysis techniques. The concept of employability periodically developed over time and manifested as a multi-dimensional facet. There were four major contributing components such as organizational, governmental, and higher educational, and individual that affected its evolution. The term perceived employability has been driven from the individual perspective of employability which in turn is rooted in the employability concept and refers to perceptions of individuals about the possibility of their skills for potential employment or a job. Perceived employability is also used by researchers as an approach to examining the concept of employability in the literature and is affected by personal and contextual factors. In addition, as descriptive analysis results revealed, the research tendencies were found to be growing in the studied field. In addition, researchers are enlarging efforts to unveil associations amongst various dominions of discipline in perceived 
employability as indicated by co-authorship analysis. Institutes were found propagating their works in reputed peer-reviewed journals. Besides, the citation analysis at the country level demonstrated a high scientific research production on the record of the United Kingdom in terms of citation and publication. Studies pertinent to UK-based institutions and authors gained prominence on scale developing aspects as initially exploring the themes and their associated constructs. On the contrary, India, Nigeria, South Africa, Sweden, the United States, and Bangladesh witnessed a quantum jump on works unveiling factorial relations with the concept of perceived employability considering external and internal effects. Through a synoptic overview of the current literature, it was found that the dominance of the quantitative methodologies adopted by researchers is on an upward growth trajectory. A co-authorship association amongst authors between 2008 and 2021 was also highlighted through the co-authorship analysis. In addition, the co-occurrence analysis network showed a high occurrence of the themes; "employability and perceived employability" within other growing relative constructs such as employment, university commitment, career development, higher education, part-time work, career planning, graduate employability, job search, curriculum designs, employability skills, soft skills, career decision, selfefficacy, college students, emotional intelligence, social support, graduate attributes, satisfaction, social support, work experience, extracurricular activities, university students, and entrepreneurship education. This reveals 'researchers' tendency to further explore the themes though the studied field witnessed an enlargement through newly other validated constructs. However, the study revealed a lack of qualitative and comparative studies in the area of perceived employability. So, Social and moderation effects on the model were also rare. The present study was restricted to only the Scopus database. Researchers can further consider the inclusion of databases such as Web of Science, Google Scholar, Proquest, IEEE Explore for better inspection. Besides, the present study largely included studies on 'students' perceived employability in the higher education arena. Furthermore, authors can take into account the studies from 'employees' perceived employability and other stakeholders. VOS viewer was used as a bibliometric instrument to carry out the analysis in the present study whereas there are other tools such as Gephi, HistCite, Bib excel, etc. that can facilitate an identical analysis providing better visualization that can be considered in future studies. For a better and clear picture of networks amongst different units of analysis and describing papers both in terms of popularity and prestige, a variety of science mapping analysis software like SciMat, CiteNet Explore, Cite Space, and Sci2tool can be used by future researchers. Application of mentioned tools would probably lead to an in-depth examination of papers allowing a comprehensive analysis which helps in identification of reputed research papers in the studied area. Despite the mentioned limitations, the present study is counted as a comprehensive overview of the research on 'students' perceived employability. It might provide immense benefits to academicians and practitioners alike and assist the advancement of research on this topic. 


\section{References}

Abdullah, D., Alsagoff, S., Ramlan, M., \& Sabran, M. (2014). Measuring Student Performance, Student Satisfaction and its Impact on Graduate Employability. International Journal of Academic Research in Business and Social Sciences, 4(4). https://doi.org/10.6007/ijarbss/v4$\underline{\mathrm{i} 4 / 763}$

Abelha, M., Fernandes, S., Mesquita, D., Seabra, F., \& Ferreira-Oliveira, A. (2020). Graduate Employability and Competence Development in Higher Education-A Systematic Literature Review Using PRISMA. Sustainability, 12(15), 5900. https://doi.org/10.3390/su12155900

Alrifai, A., \& Raju, V. (2019). The Employability Skills of Higher Education Graduates: A Review of Literature. IARJSET, 6(3), 83-88. https://doi.org/10.17148/iarjset.2019.6315

Artess, J., Hooley, T., \& Mellors-Bourne, R. (2017). Employability: A review of the literature 2012-2016. Higher Education Academy. https://www.advance-he.ac.uk/knowledgehub/employability-review-literature-2012-2016.

Batistic, S., \& Tymon, A. (2017). Networking behaviour, graduate employability: a social capital perspective. Education + Training, 59(4), 374-388. https://doi.org/10.1108/et-06-2016-0100

Brannan, D., Biswas-Diener, R., Mohr, C., Mortazavi, S., \& Stein, N. (2013). Friends and family: A cross-cultural investigation of social support and subjective well-being among college students. The Journal of Positive Psychology, 8(1), 65-75. https://doi.org/10.1080/17439760.2012.743573

Chowdhury, T., \& Miah, M. (2019). Perceptions of students and employers regarding employability skills for entry-level positions in marketing and sales. Australian Journal of Career Development, 28(1), 3-13. https://doi.org/10.1177/1038416217751566

Dahou, K., \& Hacini, I. (2018). Successful Employee Empowerment: Major Determinants in the Jordanian Context. Eurasian Journal of Business and Economics, 11(21), 49-68. https://doi.org/10.17015/ejbe.2018.021.03

De Cuyper, N., Van der Heijden, B., \& De Witte, H. (2011). Associations between perceived employability, employee well-being, and its contribution to organizational success: a matter of psychological contracts? The International Journal of Human Resource Management, 22(7), 1486-1503. https://doi.org/10.1080/09585192.2011.561962

Di Fabio, A., \& Kenny, M. (2014). The Contributions of Emotional Intelligence and Social Support for Adaptive Career Progress among Italian Youth. Journal Of Career Development, 42(1), 48-59. https://doi.org/10.1177/0894845314533420

Dinc, M. S., \& Budic, S. (2016). The Impact of Personal Attitude, Subjective Norm, and Perceived Behavioural Control on Entrepreneurial Intentions of Women. Eurasian Journal of Business and Economics, 9(17), 23-35. https://doi.org/10.17015/ejbe.2016.017.02

Donald, W., Ashleigh, M., \& Baruch, Y. (2018). Students' perceptions of education and employability. Career Development International, 23(5), 513-540. https://doi.org/10.1108/cdi-09-2017-0171

Fajaryati, N., \& Akhyar, M. (2020). The Employability Skills Needed to Face the Demands of Work in the Future: Systematic Literature Reviews. Open Engineering, 10(1), 595-603. https://doi.org/10.1515/eng-2020-0072

Grazier, B. (1998). Employability: Concepts and Policies, (pp. 1-20). European Employment Observatory: European Commission. 
Students Perceived Employability: A Systematic Literature Search and Bibliometric Analysis

Guilbert, L., Bernaud, J., Gouvernet, B., \& Rossier, J. (2015). Employability: review and research prospects. International Journal for Educational and Vocational Guidance, 16(1), 69-89. https://doi.org/10.1007/s10775-015-9288-4

Hazelzet, E., Picco, E., Houkes, I., Bosma, H., \& de Rijk, A. (2019). Effectiveness of Interventions to Promote Sustainable Employability: A Systematic Review. International Journal of Environmental Research and Public Health, 16(11), 1985. https://doi.org/10.3390/ijerph16111985

Huang, R., \& Turner, R. (2018). International experience, universities support, and graduate Employability-perceptions of Chinese international students studying in UK universities. $\begin{array}{llll}\text { Journal of Education } & \text { 175-189. }\end{array}$ https://doi.org/10.1080/13639080.2018.1436751

Ishengoma, E., \& Vaaland, T. (2016). Can university-industry linkages stimulate student employability? Education + Training, 58(1), 18-44. https://doi.org/10.1108/et-11-2014-0137

Jackson, D., \& Wilton, N. (2017). Perceived Employability among undergraduates and the importance of career self-management, work experience, and individual characteristics. Higher Education Research and Development, 36(4), 747-762. https://doi.org/10.1080/07294360.2016.1229270

Jones, P., Pickernell, D., Fisher, R., \& Netana, C. (2017). A tale of two universities: graduates perceived value of entrepreneurship education. Education + Training, 59(7/8), 689-705. https://doi.org/10.1108/et-06-2017-0079

Kanuka, H., \& Smith, E. (2018). Perceptions of the content and employability value of credentialed teaching certificates. International Journal for Academic Development, 24(1), 7385. https://doi.org/10.1080/1360144x.2018.1545130

Misra, R. K., \& Khurana, K. (2017). Employability skills among information technology professionals: A literature review. Procedia Computer Science, 122, 63-70. https://doi.org/10.1016/j.procs.2017.11.342

Ngoma, M., \& Dithan Ntale, P. (2016). Psychological capital, career identity and graduate employability in Uganda: the mediating role of social capital. International Journal of Training and Development, 20(2), 124-139. https://doi.org/10.1111/ijtd.12073

Onyishi, I., Enwereuzor, I., Ituma, A., \& Omenma, J. (2015). The mediating role of perceived employability in the relationship between core self-evaluations and job search behaviour. Career Development International, 20(6), 604-626. https://doi.org/10.1108/cdi-09-2014-0130

Pitan, O., \& Muller, C. (2019). Students' self-perceived employability (SPE). Higher Education, Skills and Work-Based Learning, 10(2), 355-368. https://doi.org/10.1108/heswbl-03-2019$\underline{0040}$

Pollack, J., Vanepps, E., \& Hayes, A. (2012). The moderating role of social ties on entrepreneurs' depressed affect and withdrawal intentions in response to economic stress. Journal of Organizational Behavior, 33(6), 789-810. https://doi.org/10.1002/job.1794

Räty, H., Hytti, U., Kasanen, K., Komulainen, K., Siivonen, P., \& Kozlinska, I. (2019). Perceived employability and ability self among Finnish university students. European Journal of Psychology of Education, 35(4), 975-993. https://doi.org/10.1007/s10212-019-00451-7

Rothwell, A., \& Jewell, S (2016). The Relationship between 'Graduates' perceived Employability Attributes and Employability Gap in Egypt: The Moderating Roles of Core SelfEvaluation and University Branding. International Journal of Research in Engineering, Social Sciences, 10(3), 21-34. https://doi.org/10.1177/1469787414544875 
Rothwell, A., Herbert, I., \& Rothwell, F. (2008). Self-perceived employability: Construction and initial validation of a scale for university students. Journal of Vocational Behaviour, 73(1), 112. https://doi.org/10.1016/i.jvb.2007.12.001

Rothwell, A., Jewell, S., \& Hardie, M. (2009). Self-perceived employability: Investigating the responses of post-graduate students. Journal of Vocational Behaviour, 75(2), 152-161. https://doi.org/10.1016/i.jvb.2009.05.002

Sumanasiri, E., Yajid, M., \& Khatibi, A. (2015). Review of literature on Graduate Employability. Journal of Studies in Education, 5(3), 75. https://doi.org/10.5296/ise.v5i3.7983

Surwase, G., Sagar, A., Kademani, B. S., \& Bhanumurthy, K. (2011). Co-citation Analysis: An Overview. In Kademani B.S. et al. (Eds) Beyond Librarianship: Creativity, Innovation and Discovery (BOSLA National Conference Proceedings), 16-17 September, Mumbai, India.

Tranfield, D., Denyer, D., \& Smart, P. (2003). Towards a Methodology for Developing EvidenceInformed Management Knowledge by Means of Systematic Review. British Journal of Management, 14(3), 207-222. https://doi.org/10.1111/1467-8551.00375

Trullas, I., Simo, P., Fusalba, O. R., Fito, A., \& Sallan, J. M. (2018). Student-perceived organizational support and perceived Employability in the marketing of higher education. Journal of Marketing for Higher Education, 28(2), 266-281. https://doi.org/10.1080/08841241.2018.1488334

Van Dam, K. (2004). Antecedents and consequences of employability orientation. European Journal of Work and Organizational Psychology, 13(1), 29-51. https://doi.org/10.1080/13594320344000237

Vanhercke, D., Kirves, K., De Cuyper, N., Verbruggen, M., Forrier, A., \& De Witte, H. (2015). Perceived employability and psychological functioning framed by gain and loss cycles. Career Development International, 20(2), 179-198. https://doi.org/10.1108/cdi-12-2014-0160

Williams, S., Dodd, L., Steele, C., \& Randall, R. (2015). A systematic review of current understandings of employability. Journal of Education and Work, 29(8), 877-901. https://doi.org/10.1080/13639080.2015.1102210 